\title{
Сравнительное содержание танидов в образцах двух родов семейства Geraniaceae Juss.
}

\section{A comparative content analysis of tannins in samples of two genera from the family Geraniaceae Juss.}

\author{
Ильина Л. П. ${ }^{1}$, Анцупова Т. П. ${ }^{2}$, Жамсуева Т. Ц. ${ }^{1}$ \\ Ilyina L. P. ${ }^{1}$, Antsupova T. P. ${ }^{2}$, Zhamsueva T. Ts. ${ }^{1}$ \\ ${ }^{1}$ Бурятская государственная сельскохозяйственная академия имени В. Р. Филиппова, г. Улан-Удэ, Россия. \\ E-mail:larisap11@mail.ru \\ ${ }^{2}$ Восточно-Сибирский государственный университет технологий и управления, г. Улан-Удэ, Россия. \\ E-mail: antsupova-bot@mail.ru \\ ${ }^{1}$ Buryat State Academy of Agriculture named after V. Philippov, Ulan-Ude, Russia. E-mail: larisap11@mail.ru \\ ${ }^{2}$ East-Sibirian State University of Technology and Management, Ulan-Ude, Russia, E-mail: antsupova-bot@mail.ru
}

\begin{abstract}
Peфepam. В статье представлены результаты исследования содержания танидов в образцах двух родов семейства Geraniaceae Juss., которые меняются в зависимости от органов растений, от места произрастания и внешних факторов окружающей среды. Наибольшее содержание танидов обнаружено у журавельника цикутового $(29,15$ $\%$ в траве), наименьшее - у герани ложносибирской (9,09 \% в траве). В корневой системе наибольшее содержание дубильных веществ выявлено у герани ложносибирской $(27,29 \%)$, наименьшее - у журавельника цикутового $(9,42 \%)$. В сухую и более прохладную погоду синтез танидов интенсивнее, чем в более влажную и теплую.
\end{abstract}

Ключевые слова. Дубильные вещества, надземные органы, подземные органы, погода, семейство Geraniaceae Juss.

Summary. The article presents the results of study on the content of tannins in the samples of two genera of the family Geraniaceae Juss., which are changing depending on the plant organs, the place of growth and external environmental factors. The highest content of tannins was found in Erodium cicutarium (29,15\% in the grass), the lowest - in Geranium pseudosibiricum $(9,09 \%$ in the grass). In the root system the highest content of tannins was detected in Geranium pseudosibiricum $(27,29 \%)$, the lowest - in Erodium cicutarium (9,42 \%). In dry and cooler weather, tannin's synthesis is more intense than in wetter and warmer weather.

Key words. Family Geraniaceae Juss., overground organs, tannins, underground organs, weather.

Растения, произрастающие в природе, менее изучены по сравнению с культурными растениями, но имеют не меньший спрос среди населения как в промышленных масштабах, например, в лесопромышленном комплексе, так и для индивидуального пользования в виде заготовок. В их число входят лекарственные растения, к которым относятся герани. Герани обладают различными полезными свойствами, связанными с содержанием дубильных веществ (танидов, танинов), так как герани используют как дезинфицирующие, ранозаживляющие, вяжущие средства и т.д. (Телятьев, 1985; Минаева, 1991). Исследования растений семейства Geraniaceae на содержание танидов мы проводим с 2011 г. (Ильина, Анцупова, 2013; 2016а; 2016б; 2018). Целью нашей работы на данном этапе является сравнительное изучение содержания дубильных веществ в растительных образцах двух родов семейства, собранных в один временной период (2015 г.) на территории Бурятии с учетом влияния внешних факторов окружающей среды.

Объектами исследования послужили три вида рода герань (Geranium L.) и 2 вида рода журавельник, или аистник (Erodium L'Her.), собранные в пяти районах республики и в окрестностях г. Улан- 
Удэ: герань Власова - G. wlassovianum Fischer ex Link, г. ложносибирская - G. pseudosibiricum J. Mayer [= G. coeruleum Patrin], г. сибирская - G. sibiricum L., журавельник цикутовый - Erodium cicutarium (L.) L'Her., ж. Стефана - E. stephanianum Willd. Выделение танидов из растительного сырья проводили экстрагированием водой и последующим титрованием по принятой методике (Государственная ..., 1989).

Содержание дубильных веществ в растительном материале показано в таблице 1. Согласно данным таблицы, у двух видов гераней: герани Власова и г. ложносибирской - в корневищах и корнях накопление танидов больше, чем в надземной части. У герани сибирской и представителей рода журавельник, наоборот, наблюдается превышение танидов в траве по сравнению с подземными органами. Возможно, это связано с внешним сходством у них корневой системы, она намного меньше по сравнению с массивной подземной частью у других представителей рода Geranium. В образцах рода Geranium наибольшее содержание дубильных веществ наблюдается в корнях герани ложносибирской $(27,29 \%)$, а в траве - у г. сибирской $(25,10 \%)$. В образцах рода Erodium больше всего танидов отмечено в траве журавельника цикутового (29,15 \%), а в подземной части - у ж. Стефана (12,05 \%). Район произрастания также влияет на синтез биологически активных веществ. Например, у журавельника Стефана, образцы которого были собраны в один день - 31 июля, но в разных районах, содержание дубильных веществ в надземных и подземных органах растения из Иволгинского района больше $(24,81 \%$ и $12,05 \%$, соответственно), чем в надземных и подземных органах растения из Тарбагатайского района ( $19,50 \%$ и $9,42 \%$, соответственно).

Таблица 1

Содержание танидов в образцах двух родов семейства Geraniaceae,

\% от массы абсолютно-сухого сырья

\begin{tabular}{|c|c|c|c|c|}
\hline Вид растений & Район сбора & $\begin{array}{c}\text { Дата } \\
\text { сбора }\end{array}$ & $\begin{array}{c}\text { Надземная } \\
\text { часть }\end{array}$ & $\begin{array}{c}\text { Подземная } \\
\text { часть }\end{array}$ \\
\hline Geranium wlassovianum & Окрестность г. Улан-Удэ & 2 июля & $13,62 \pm 0,03$ & $19,77 \pm 0,04$ \\
\hline \multirow{3}{*}{$\begin{array}{c}\text { Geranium pseudosibiricum } \\
{[\text { G. coeruleum }]}\end{array}$} & Иволгинский & 10 июня & $23,52 \pm 0,03$ & $24,13 \pm 0,04$ \\
\hline \multirow{4}{*}{ Geranium sibiricum } & Прибайкальский & 18 июня & $22,74 \pm 0,02$ & $27,29 \pm 0,03$ \\
\cline { 2 - 5 } & Окрестность г. Улан-Удэ & 2 июля & $20,58 \pm 0,05$ & $21,47 \pm 0,03$ \\
\cline { 2 - 5 } & Селенгинский & 15 августа & $9,09 \pm 0,04$ & $16,82 \pm 0,03$ \\
\hline & Селенгинский & 14 июля & $21,35 \pm 0,01$ & $10,26 \pm 0,03$ \\
\hline & Джидинский & 25 июля & $22,07 \pm 0,03$ & $21,19 \pm 0,02$ \\
\cline { 2 - 5 } & Джидинский & 27 июля & $21,83 \pm 0,04$ & $10,99 \pm 0,03$ \\
\cline { 2 - 5 } & Джидинский & 27 июля & $25,10 \pm 0,03$ & $14,19 \pm 0,03$ \\
\hline \multirow{2}{*}{ Erodium cicutarium } & Прибайкальский & 2 июля & $24,26 \pm 0,05$ & $11,88 \pm 0,02$ \\
\hline \multirow{2}{*}{ Erodium stephanianum } & Джидинский & 24 июля & $29,15 \pm 0,04$ & $8,90 \pm 0,03$ \\
\hline & Тарбагатайский & 31 июля & $19,50 \pm 0,02$ & $9,42 \pm 0,02$ \\
\cline { 2 - 5 } & Иволгинский & 31 июля & $24,81 \pm 0,3$ & $12,05 \pm 0,04$ \\
\hline
\end{tabular}

Химический состав растений зависит и от других факторов, например, от метеорологических условий (табл. 2). Проследить влияние температурного режима, количество осадков и влажности воздуха можно на примере герани ложносибирской. В июне при самой низкой температуре и в сухую погоду идет усиление синтетических процессов и в траве (до $23,52 \%$, и в корневищах с корнями (до $27,29 \%$ ). В июле в жаркое и более дождливое время синтез дубильных веществ замедляется во всех органах растений (20,58 \% в надземной части и 21,47 \% в подземной части). В августе, когда становится прохладнее и более влажно, несмотря на уменьшение осадков, танидов содержится меньше всего (9,09\% в траве и $16,82 \%$ в корнях).

Таким образом, наибольшее содержание танидов обнаружено у журавельника цикутового (29,15\% в траве), наименьшее - у герани ложносибирской (9,09 \% в траве). В корневой системе наибольшее содержание дубильных веществ выявлено у герани ложносибирской $(27,29 \%)$, наименьшее у журавельника цикутового (9,42 \%). В сухую и более прохладную погоду синтез танидов интенсивнее, чем в более влажную и теплую. 
Метеоданные Республики Бурятии (по данным метеостанции г. Улан-Удэ, 2015 г.)

\begin{tabular}{|c|c|c|c|}
\hline Месяц & $\begin{array}{c}\text { Среднесуточная } \\
\text { температура, }{ }^{\circ} \mathrm{C}\end{array}$ & $\begin{array}{c}\text { Среднемесячное } \\
\text { выпадение осадков, мм }\end{array}$ & $\begin{array}{c}\text { Среднемесячная } \\
\text { влажность воздуха, \% }\end{array}$ \\
\hline июнь & 17,8 & 14,2 & 32,1 \\
\hline июль & 23,1 & 50,3 & 33,5 \\
\hline август & 20,4 & 18,1 & 41,6 \\
\hline
\end{tabular}

\section{ЛИТЕРАТУРА}

Государственная Фармакопея СССР. - М.: Медицина, 1989. - Вып. 2. - 400 с.

Ильина Л. П., Анцупова Т. П. Динамика содержания дубильных веществ в видах герани // Изучение, сохранение и восстановление естественных ландшафтов: Сб. ст. ІІІ междунар. науч.-практ. конф. (7-10 октября 2013 г., Волгоград). - М.: Планета, 2013. - С. 79-82.

Ильина Л. П., Аниупова Т. П. Дубильные вещества представителей семейства Geraniaceae Бурятии // Междунар. научно-исслед. журн, 2016а. - № 5 (47). - С. 73-74.

Ильина Л. П., Анцупова Т. П. Накопление дубильных веществ в видах герани в зависимости от фазы вегетации // Вестник Бурятской государственной сельскохозяйственной академии им. В. Р. Филиппова. - 2016б. - № 4 (45). - C. 22-26.

Ильина Л. П., Анцупова Т. П. Зависимость содержания дубильных веществ от фитоценотической приуроченности растений рода Geranium L. в Бурятии // Естественные и технические науки, 2018. - № 4 (118). - С. $27-34$.

Минаева В. Г. Лекарственные растения Сибири. - Новосибирск: Наука. Сиб. отделение, 1991. - 431 с.

Tелятьев В. В. Полезные растения Центральной Сибири. - Иркутск: Восточно-Сибирское книжное изд-во, 1985. $-384 \mathrm{c}$. 